\title{
Hubungan antara umur dan fekunditas telur ikan gurame (Osphronemus gouramy)
}

\section{Relation between age and fecundity of giant gouramy (Osphronemus gouramy)}

\author{
Arif Habib Fasya ${ }^{1 *}$, Hilda Nabila ${ }^{1}$, Hapsari Kenconojati ${ }^{1}$, Mohammad Faizal Ulkhaq ${ }^{1}$ \\ ${ }^{1}$ Program Studi Akuakultur, Universitas Airlangga PSDKU Banyuwangi, Jl. Wijaya Kusuma No. \\ 113 Giri, Banyuwangi 68425, Jawa Timur. \\ *Email: arifhabibfasya@fpk.unair.ac.id
}

Received : 17 March 2020

Accepted : 19 April 2020

Publish : 31 April 2020

\begin{abstract}
Abstrak
Kebutuhan ikan gurame (Osphronemus gouramy) terus meningkat, hal ini dapat dilihat dari perdagangan ikan gurame yang sudah dimulai pada tahap masih telur, sehingga diperlukan penelitian yang mempengaruhi jumlah telur (fekunditas) dari induk ikan gurami. Pada penelitian ini bertujuan untuk mengetahui hubungan antara umur dan fekunditas ikan gurame. Metode penelitian yang digunakan deskritif komparatif. Induk ikan gurame terbagi menjadi 3 berdasarkan umurnya, kolam A induk berumur 2,5 tahun, kolam B berumur 4 tahun dan kolam $\mathrm{C}$ berumur 8 tahun. Pengamatan dilakukan dengan cara pengambilan telur dari sarang pada masing-masing kolam kemudian dihitung secara manual. Hasil pengamatan menunjukan bahwa induk yang berumur 4 tahun memiliki tingkat fekunditas paling tinggi.

Keyword : Umur, Fekunditas, ikan gurame (Osphoronemus gourami)

Abstract

The need for gouramy (Osphronemus gouramy) continues to increase, this can be seen from the gouramy trade which has begun at the egg stage, so research is needed that affects the number of eggs (fecundity) of the gouramy parent. In this study aims to determine the relationship between age and fecundity of gouramy. The research method used is comparative descriptive. Main gouramy fish is divided into 3 based on their age, pond A is 2.5 years old, pond B is 4 years old and pond $\mathrm{C}$ is 8 years old. Observations were made by taking eggs from the nest in each pond then counted manually. The observations showed that the parent who was 4 years old had the highest level of fecundity.
\end{abstract}

Keyword : Age, Fecundity, Osphoronemus gourami 


\section{PENDAHULUAN}

Ikan gurame (Osphronemus gouramy) merupakan salah satu komoditas penting perikanan air tawar. Cita rasa gurame yang gurih serta tekstur dagingnya yang tidak lembek menjadikan ikan gurame digemari dikalangan masyarakat khususnya di Pulau Jawa. Dilihat dari segi bisnis, budidaya ikan gurame termasuk usaha perikanan yang menguntungkan jika dibandingkan dengan jenis ikan tawar lainnya.

Hal ini ditandai dengan harga jual ikan gurame yang lebih mahal dan lebih stabil dipasaran (Pratama dkk., 2018). Keunggulan ikan gurame dibandingkan ikan air tawar lainnya adalah rasa dan kandungan gizinya tinggi, bersifat herbivora sehingga biaya pemeliharaannya relatif rendah dan dapat hidup pada lingkungan perairan berkadar oksigen rendah dengan adanya alat pernafasan tambahan (Nugroho, 2012).

$\begin{array}{ccr}\text { Selain } & \text { itu } & \text { gurame } \\ \text { (Osphronemus } & \text { gouramy) } & \text { memiliki }\end{array}$ kandungan gizi yang tinggi berupa lemak 2,20-2,79 \%, protein 18,71$20,67 \%$, serta beberapa jenis mineral seperti fosfor $72,4 \%$, calcium 13,75 $\%$ dan kalium 13,03 \% (Santoso, 2009). Namun ikan gurame juga mempunyai kekurangan, antara lain pertumbuhannya yang tergolong lambat dibandinkan ikan air tawar lainnya (Mauluddin, 2009). Budidaya ikan gurame baik dari sektor pembenihan maupun pembesaran sudah banyak dilakukan.

Pembenihan gurame memiliki peranan penting dalam pemenuhan kebutuhan benih, terutama dalam proses penetasan telur. Permasalahan yang dihadapi dalam penetasan ikan gurame yaitu daya tetas telur dan tingkat kelulushidupan yang masih rendah. Pada fase itu kondisinya masih rentan terhadap perubahan lingkungan (Pratama dkk., 2018).

Permasalahan dalam budidaya gurame diduga sebagai penyebab ikan gurame tumbuh lambat adalah tidak jelasnya manajemen pengelolaan induk yang dilakukan di tingkat pembenih dan jenis ataupun umur pemakaian induk tidak dipertimbangkan dengan baik (Nugroho, 2012). 
Permasalahan lain dalam pembenihan gurame yaitu rendahnya fekunditas telur (Nugroho, 2008).

Fekunditas merupakan salah satu faktor yang berpengaruh terhadap tingkat produktivitas ikan. Fekunditas adalah jumlah telur matang yang dikeluarkan oleh induk betina atau jumlah telur yang dikeluarkan pada waktu pemijahan. Terdapat beberapa kegunaan menentukan fekunditas diantaranya, sebagai studi sistemtik atau studi mengenai ras, dinamika populasi, produktivitas, potensi reproduksi (Tarigan, 2017).

\section{Menurut Harianti} fekunditas dipengaruhi oleh lingkungan terutama faktor makanan. jumlah telur dipengaruhi oleh bobot tubuh induk. Jumlah fekunditas akan semakin tinggi jika penurunan bobot tubuh induk setelah memijah semakin tinggi dan diameter telur yang dihasilkan semakin kecil.

$$
\text { Faktor lain yang }
$$

mempengaruhi adalah perbedaan jumlah telur antara masing-masing spesies yang bergantung pada kemampuan individu untuk menghasilkan telur (Nikolsky 1969).
Menurut Lagler et al. (1962) bahwa jumlah telur yang diproduksi oleh induk betina selain dipengaruhi oleh berat biomas juga dipengaruhi oleh umur induk. Maka informasi mengenai hubungan antara umur induk gurame dan fekunditas akan menjadi informasi yang sangat penting untuk upaya pengembangan di bidang budidaya.

\section{METODE PENELITIAN}

\section{Bahan}

Bahan yang digunakan dalam penelitian ini adalah induk betina ikan gurame sebanyak 150 ekor yaitu masing-masing 50 ekor pada kolam A dengan umur 2,5 tahun, 50 ekor pada kolam B dengan umur 4 tahun dan 50 ekor pada kolam $\mathrm{C}$ dengan umur 8 tahun. Selain itu, jumlah masingmasing telur yang dihasilkan yaitu sebanyak 4691 butir yang berasal dari 1318 butir dari induk pada kolam A, 2299 butir dari induk pada kolam B dan 1074 butir dari induk pada kolam C.

Alat
Alat yang digunakan
dalam penelitian ini adalah bak
penetasan yang berupa bak


plastik, saringan kecil dan hand counter untuk menghitung jumlah telur secara langsung.

\section{Metode pengambilan data}

Data penelitian berupa jumlah telur pada masing-masing kolam (kolam A, B, C dengan umur 2,5 tahun, 4 tahun, 8 tahun) selama satu bulan. Metode yang digunakan adalah dengan diskriptif komparatif grafik dan menghubungkan antara umur dan fekunditas.

Pengamatan dilakukan

pada bulan Desember 2019 Januari 2020. Induk ikan gurame (Osphronemus gouramy) yang dipelihara terbagi menjadi 3 kolam berdasarkan umurnya yaitu kolam A induk berumur 2,5 tahun, kolam $\mathrm{B}$ induk berumur 4 tahun, kolam $\mathrm{C}$ induk berumur 8 tahun. Pengambilan telur dilakukan pada pagi bertujuan menghindari fluktuasi suhu yang tinggi dan dilakukan dengan hatihati. Pengambilan telur dilakukan dengan cara mengambil sarang telur pada sosog, setiap kolam terdapat 3 sosog (tempat sarang telur). Setelah itu, sarang pada masing - masing sosog dihitung jumlah telur seluruhnya pada bak yang sudah disiapkan. Untuk menghitung rata-rata fekunditas per induk dilakukan dengan cara menghitung jumlah total telur yang didapat dibagi dengan jumlah sosog. Sosog yang diambil yaitu 3 sosog pada masing-masing kolam.

\section{Analisa Data}

Analisa data mengunakan regresi linear yaitu hubungan antara umur dan fekunditas. Selanjutnya data disajikan dalam bentuk table dan grafik dan dianalisis secara deskriptif untuk menarik kesimpulan dari data tersebut.

\section{HASIL DAN PEMBAHASAN}

Fekunditas pada masingmasing kolam berbeda berdasarkan dari umur induk ikan gurame. Hasil penghitugan fekunditas induk gurame dapat dilihat pada gambar 1 . Hasil dari penelitian menunjukan bahwa jumlah telur induk gurame pada kolam A yaitu 1318 butir. Induk pada kolam $\mathrm{C}$ menghasilkan fekunditas 1074 butir dan fekunditas pada kolam B yaitu 2299. Fekunditas 
paling rendah ditemukan pada kolam $\mathrm{C}$, sedangkan paling tinggi pada kolam B. Hal tersebut menunjukkan bahwa pada kolam B dengan induk berumur 4 tahun memiliki fekunditas tertinggi. Fekunditas pada kolam $\mathrm{C}$ lebih sedikit daripada kolam A diduga karena induk pada kolam $\mathrm{C}$ yang berusia 8 tahun sudah masuk usia afkir atau tidak produktif lagi. Induk pada kolam A yang berumur 2,5 tahun diduga masih dalam umur pemijahan awal. Menurut SNI (2000) induk gurame siap memijah pada umur 30 - 36 bulan serta akan menghasilkan $1.500-2.500$ butir $/ \mathrm{kg}$.

\section{Gurame}

(Osphronemus gouramy) yang masih muda atau dalam awal masa pemijahan biasanya menghasilkan telur dengan fekunditas yang rendah serta kualitas telur yang tidak lebih baik dari gurame yang sudah berkali-kali memijah.

\section{Sedangkan gurame yang} memasuki umur produkif fekunditasya maksimal dan lebih stabil. Menurut Lagler et al. (1962) bahwa jumlah telur yang diproduksi oleh induk betina sangat dipengaruhi oleh umur induk, ukuran, kondisi ikan. Data umur yang dihubungkan dengan data panjang dapat memberikan keterangan tentang umur pada waktu ikan pertama kali matang gonad, pertumbuhan dan reproduksi (Persada dkk., 2016).

Induk gurame (Osphronemus gouramy) yang akan memijah untuk pertama kalinya mempunyai fekunditas yag rendah. Untuk mencapai matang gonad dibutuhkan waktu yang lebih lama dari induk yang sudah berkali-kali memijah. Menurut Arifin et al. (2019) proses pematangan gonad induk gurame yang telah beberapa kali memijah lebih cepat daripada indukan yang pertama kali memijah.

Effendie (2002) menjelaskan bahwa ikan akan menunjukkan penambahan jumlah telur yang cepat pada umur-umur muda, dan kemudian akan diikuti dengan penambahan yang semakin bertambah dan berkurang dan terus menurun mencapai keadaan yang tetap pada waktu memasuki umur tidak produktif. Ikan-ikan muda yang pertama kali memijah tentunya juga akan memiliki jumlah telur yang lebih sedikit dibandingkan dengan ikan-ikan yang pernah memijah sebelumnya. Induk gurame pada 
kolam C memiliki fekunditas paling rendah. Umur induk pada kolam C paling tua daripada kolam A dan B.

Menurut Kusmini dkk (2016), semakin tua umur ikan maka semakin berkurang tingkat kesuburan organ reproduksi dan meningkatnya diameter telur pada ikan tua akan menurunkan jumlah fekunditas ikan tersebut. Beberapa spesies tertentu pada umur yang berbeda-beda memperlihatkan fekunditas yang bervariasi sehubungan dengan persediaan suplai makanan (Kariyanti dkk., 2014).

\section{KESIMPULAN}

Dari hasil penelitian dapat disimpulkan bahwa fekunditas induk ikan gurame (Osphronemus gouramy) berumur 4 tahun memiliki tingkat fekunditas yang lebih tinggi dibandingkan umur 2,5 tahun dan fekunditas paling rendah induk gurame yang berumur 8 tahun. Penelitian lebih lanjut diperlukan untuk mengetahui daya tetas telur dari indukan ikan gurame yang berumur 4 tahun.

\section{DAFTAR PUSTAKA}

Yani, A. Asependi., A.H. Kristanto., M. Legendre. 2019. New
Insights Into Giant Gourami (Osphronemus goramy) Reproductive Biology and Egg Production Control. Journal Pre-proof

Effendie, M.I. (2002). Biologi perikanan. Yayasan Pustaka Nusantara. Jogjakarta, 112 hlm.

Harianti. 2013. Fekunditas dan Diameter Telur ikan Gabus (Channa striata Bloch, 1793) di Danau Tempe, Kabupaten Wajo. Jurnal Saintek Perikanan 8(2): 18-24.

Kariyanti., S. B. A. Omar., J. Tresnati. 2014. Analisis Fekunditas dan Diameter Telur Ikan Beseng-beseng (Marosatherina ladigesi Ahl, 1936) di Sungai Pattunuang Asue dan Sungai Bantimurung, Kabupaten Maros, Sulawesi Selatan. Simposium Nasional I Kelautan dan Perikanan : 110

Kusmini, I. I., F. P. Putri, V. A. Prakoso. 2016. Bioreproduksi dan Hubungan PanjangBobot Terhadap Fekunditas Pada Ikan Lalawak (Barbonymus balleroides). Jurnal Riset Akuakultur, 11 (4): 339-345.

Lagler, K. E., J. E. Bardach, R. R. Miller. 1962. Ichthyology, 545. John Willey and Sons, Inc., New York. 
Mauluddin. 2009. Studi Mengenai morfologi dan Komposisi Sel Testikular Ikan Gurame Osphronemus gouramy Lac. Skripsi. Program Studi Teknologi dan Manajemen Akuakultur. Fakultas Perikanan dan Ilmu Kelautan. Institut Pertanian Bogor.

Nikolsky, G. V. 1969. Thoery of Fish Population Dynamics as The Biological Background for Rational Exploitation and Management of Fishery Resources. Edinburg, Olivier \& Boyd. 323 p.

Nugroho, M. H. 2008. Analisis Pendapatan dan Faktor-faktor yang Mempengaruhi Hasil Produksi Pembenihan Ikan Gurame Petani Bersertifikat SNI. Skripsi. Eksistensi Manajemen Agribisnis. Fakultas Pertanian Bogor. Bogor.

Nugroho, E. 2012. 'Endang Pamularsih' Gurame yang Jempolan. Media Akuakultur Volume 7(2): 99-102.

Persada L.G., E. Utami, \& D. Rosalina. 2016. Aspek Reproduksi Ikan Kurisi (Nemipterus furcosus) yang Didaratkan Di Pelabuhan Perikanan Nusantara Sungailiat. Akuatik. 10(2): 46-55.

Pratama, B. A., T. Susilowati., T. Yuniarti. 2018. Pengaruh Perbedaan Suhu Terhadap Lama Penetasan Lama Penetasan Telur, Daya Tetas
Telur, Kelulushidupan dan Pertumbuhan Benih Ikan Gurame (Osphronemus gouramy) Strain Bastar. Jurnal Sains Akuakultur Tropis 2(1): 59-65.

Santoso, W. 2009. Komposisi Mineral Makro dan Mikro Daging Ikan Gurame (Osphronemus gouramy) pada Berbagai Waktu Pemeliharaan. Skripsi. Program Studi Teknologi Hasil Perikanan. Fakultas Perikanan dan Ilmu Kelautan. Insitut Pertanian Bogor.

Tarigan, A. 2017. Aspek Biologi Reproduksi Ikan Selar Kuning (Selariodes leptolepis) di Perairan Selat Malaka Kecamatan Medan Belawan Provinsi Sumatera Utara. Skripsi. Program Studi Manajemen Sumberdaya Perairan. Fakultas Pertanian, Universitas Sumatera Utara. 